\title{
One-Step Hydrothermal Synthesis of N, Fe-Codoped Carbon Dots as Mimic Peroxidase and Application on Hydrogen Peroxide and Glucose Detection
}

\author{
Yan Li, ${ }^{1}$ Yuhui Weng, ${ }^{1}$ Shikong Lu, ${ }^{1}$ Meihua Xue, ${ }^{1}$ Bixia Yao, ${ }^{1}$ Wen Weng $\mathbb{D},{ }^{1,2,3}$ \\ and Tao Zheng ${ }^{4}$ \\ ${ }^{1}$ College of Chemistry, Chemical Engineering and Environment, Minnan Normal University, Zhangzhou 363000, China \\ ${ }^{2}$ Fujian Provincial Key Laboratory of Modern Analytical Science and Separation Technology, Zhangzhou 363000, China \\ ${ }^{3}$ Fujian Provincial Key Laboratory of Pollution Monitoring and Control Address, Zhangzhou 363000, China \\ ${ }^{4}$ Fujian Institute of Tropical Crops, Zhangzhou 363001, China
}

Correspondence should be addressed to Wen Weng; weng_wen@126.com

Received 7 February 2020; Revised 8 April 2020; Accepted 20 April 2020; Published 8 May 2020

Academic Editor: Zehra Durmus Copyright @ 2020 Yan Li et al. This is an open access article distributed under the Creative Commons Attribution License, which
permits unrestricted use, distribution, and reproduction in any medium, provided the original work is properly cited.

\begin{abstract}
In this paper, $\mathrm{N}, \mathrm{Fe}$-codoped carbon dots $(\mathrm{N}, \mathrm{Fe}-\mathrm{CDs})$ were synthesized from $\beta$-cyclodextrin, ethylenediamine, and ferric chloride for the first time using a convenient one-step hydrothermal method. The obtained N, Fe-CDs were characterized by various methods including transmission electron microscopy, X-ray photoelectron spectroscopy, and Fourier-transform infrared spectroscopy. The N, Fe-CDs exhibited better catalytic activity than horseradish peroxidase (HRP) and caused an evident color change for 3,3',5,5'-tetramethylbenzidine in the presence of $\mathrm{H}_{2} \mathrm{O}_{2}$. Kinetic experiments show that the apparent $\mathrm{K}_{\mathrm{m}}$ value for the $\mathrm{N}$, Fe-CDs with TMB $(0.40 \mathrm{mM})$ or $\mathrm{H}_{2} \mathrm{O}_{2}(0.35 \mathrm{mM})$ as the substrate was lower than that of $\mathrm{HRP}(0.43$ and $3.70 \mathrm{mM})$, suggesting that the $\mathrm{N}, \mathrm{Fe}-\mathrm{CD}$ h have a much higher affinity for TMB and $\mathrm{H}_{2} \mathrm{O}_{2}$ than HRP. The $\mathrm{K}_{\mathrm{m}} / \mathrm{V}_{\max }$ value for the $\mathrm{N}$, Fe-CDs $\left(21.74 \times 10^{3} \cdot \mathrm{s}\right.$ for $\left.\mathrm{H}_{2} \mathrm{O}_{2}\right)$ is significantly lower than that for HRP $\left(42.53 \times 10^{3} \cdot \mathrm{s}\right)$, suggesting that the $\mathrm{N}$, Fe-CDs have a stronger catalytic efficiency for $\mathrm{H}_{2} \mathrm{O}_{2}$ than HRP. Furthermore, a highly efficient and sensitive colorimetric detection method for glucose was developed using the $\mathrm{N}, \mathrm{Fe}-\mathrm{CDs}$ as mimic peroxidase to detect the hydrogen peroxide generated by the oxidation of glucose by glucose oxidase. The limit of detection for $\mathrm{H}_{2} \mathrm{O}_{2}$ and glucose was found to be 0.52 and $3.0 \mu \mathrm{M}$, respectively. The obtained N, Fe-codoped carbon dots, which possess simulated peroxidase activity, can potentially be used in the field of biotechnology.
\end{abstract}

\section{Introduction}

Peroxidase such as horseradish peroxidase (HRP) is a kind of natural enzyme that catalyzes the decomposition of peroxides and prevents biological cells from being damaged by toxic substances [1]. However, the natural enzyme would suffer from degradation, denaturation, and inactivation in practical applications especially under harsh conditions. The extraction, purification, and storage processes of natural peroxidase are also fussy. High price further limits its applications [2-4]. Under this background, various enzyme mimics have been developed in order to address these issues.
Recently, multiple inorganic nanomaterials, such as $\mathrm{FeOOH}$ nanorods [5], $\mathrm{Co}_{4} \mathrm{~N}$ nanowires [6], $\mathrm{WSe}_{2}$ nanosheets [7], yolk-shell nanostructured $\mathrm{Fe}_{3} \mathrm{O}_{4} @ \mathrm{C}$ magnetic nanoparticles [8], $\mathrm{MnO}_{2}$ nanowires [9], amine-grafted metal-organic frameworks (MOFs) [10], and apoferritin-paired gold clusters [11], have been found to exhibit the properties of oxidase or peroxidase-like enzymes [12]. In addition, carbon-based nanomaterials, such as graphene oxide [13], carbon nanotubes [14], carbon nanodots [15], carbonitride sheets [16], graphene quantum dots [17], and $\mathrm{C}_{3} \mathrm{~N}_{4}$ nanosheetsupported Prussian Blue nanoparticles [18], have been found to possess peroxidase-like or superoxide dismutase-like 


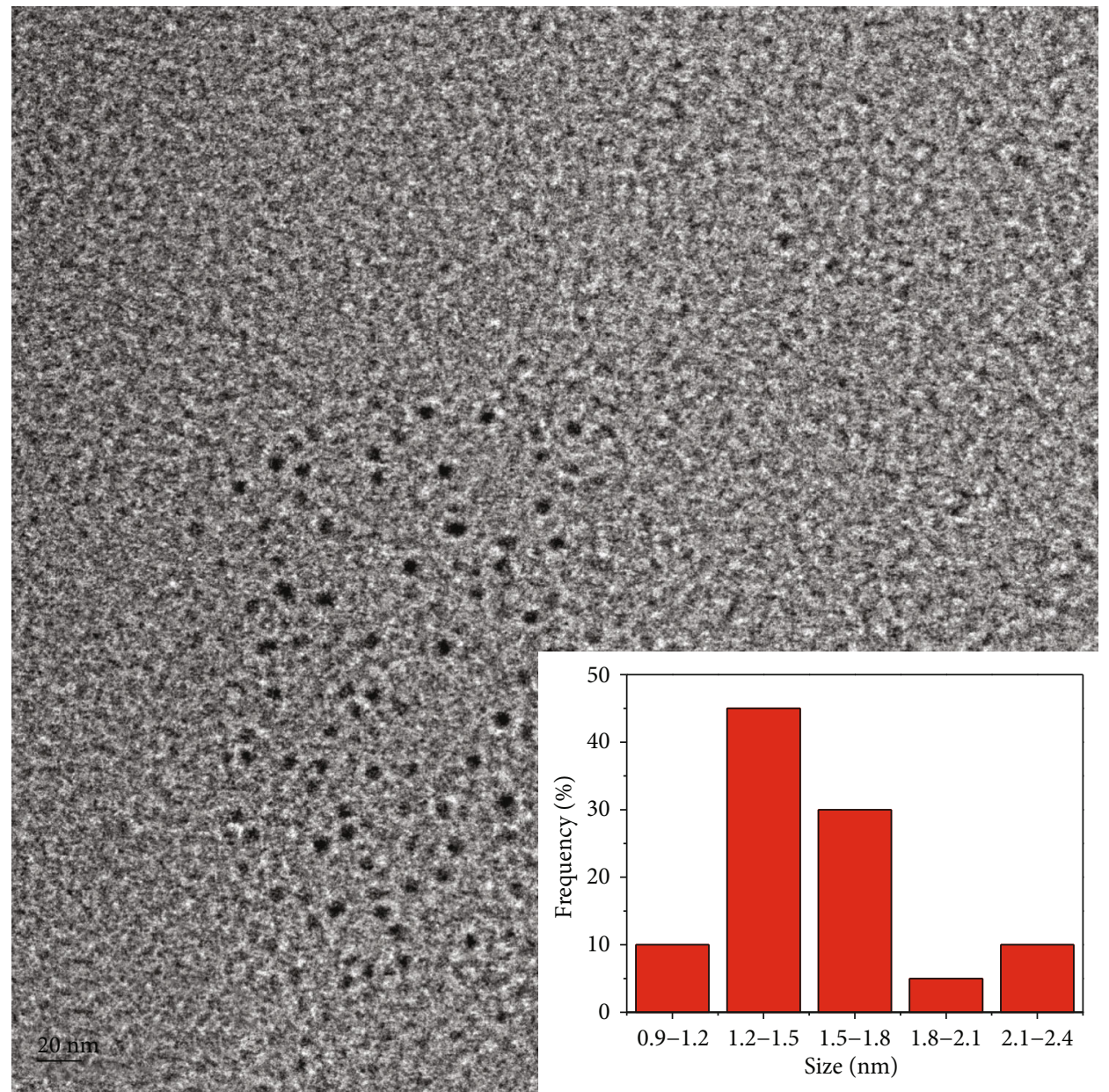

(a)

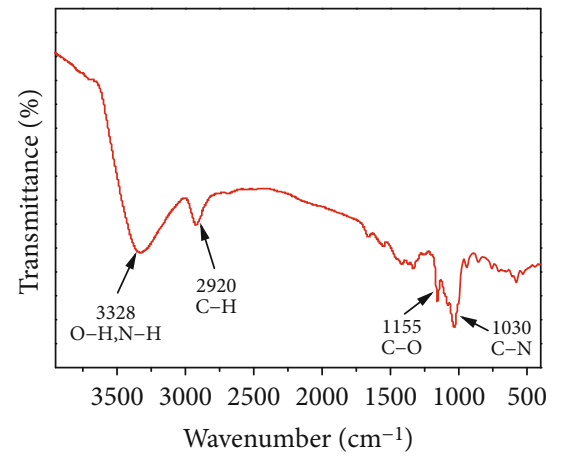

(b)

Figure 1: TEM image (a) and FTIR spectrum (b) of the obtained N, Fe-CDs.

activity [19]. This nanomaterial has been widely used in biosensor, bioimaging, catalysis, light-emitting diode device, and medical diagnosis due to their low cytotoxicity, good biocompatibility, easy functionalization, and high stability [20-27].

In this paper, a new mimic peroxidase, $\mathrm{N}, \mathrm{Fe}$-codoped carbon dots ( $\mathrm{N}, \mathrm{Fe}-\mathrm{CDs}$ ) were synthesized from $\beta$-cyclodextrin, ethylenediamine, and ferric chloride using a convenient one-step hydrothermal method. The obtained N, Fe-CDs exhibited better catalytic activity than HRP. Combining with glucose oxidase (GOx), a good colorimetric method for glucose detection was developed.

\section{Experimental Section}

2.1. Materials. $\beta$-Cyclodextrin was purchased from Shanghai Sinopharm Chemical Reagent Co. Ltd. (Shanghai, China; www.reagent.com.cn). Ethylenediamine, glucose, fructose, maltose, xylose, ascorbic acid, uric acid, $\alpha$-lactose, sucrose, terephthalic acid (TA), ferric chloride hexahydrate, and 

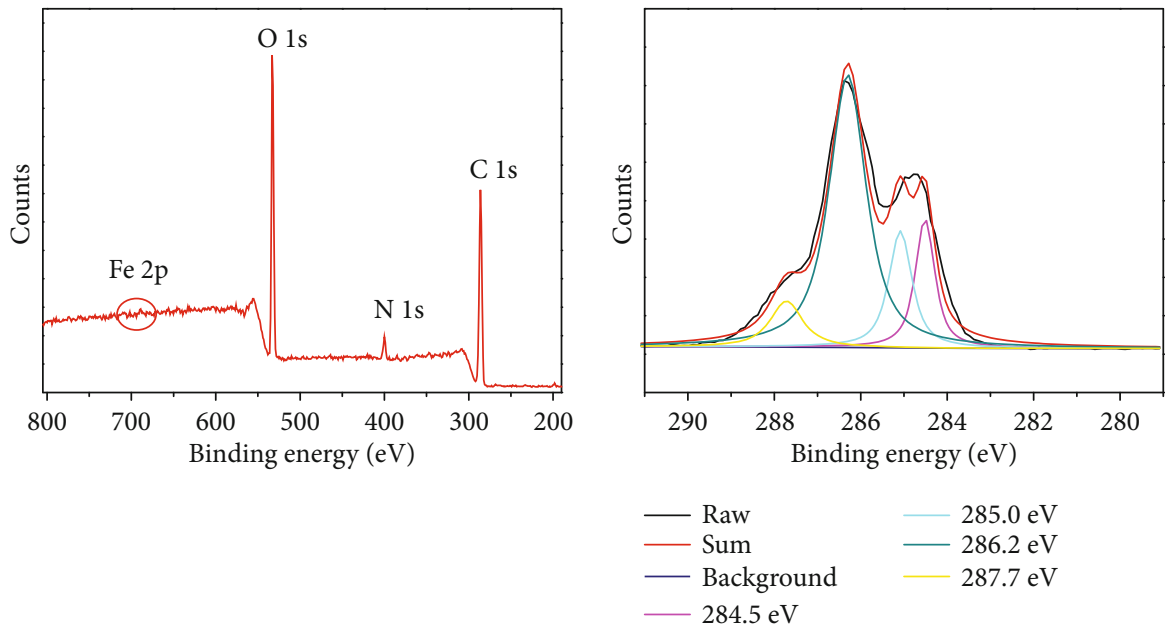

(a)

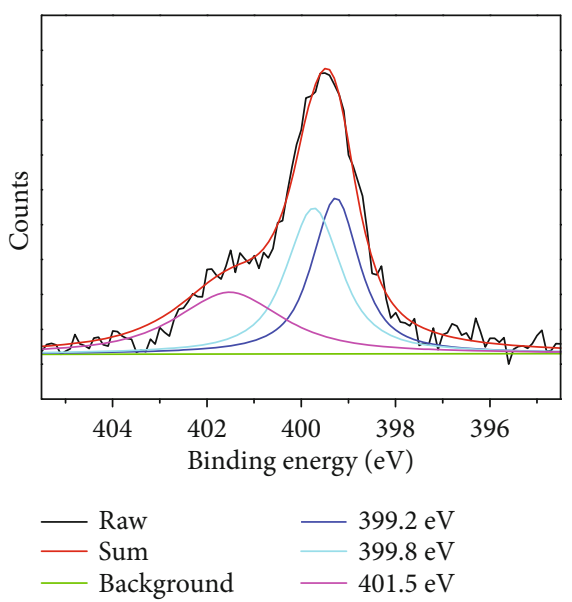

(c) (b)

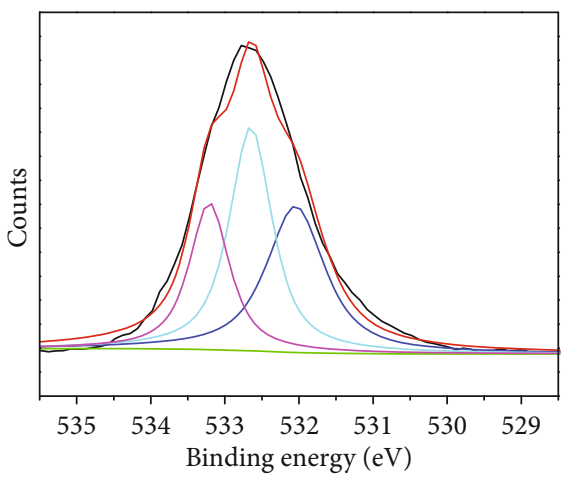

(d)

FIGURE 2: XPS spectrum of the obtained N, Fe-CDs (a). (b), (c) and (d) are the corresponding C $1 \mathrm{~s}, \mathrm{~N} 1 \mathrm{~s}$, and O $1 \mathrm{~s}$ spectra, respectively.

hydrogen peroxide $(30 \%)$ were purchased from XiLong Chemical Co. Ltd. (Guangdong, China; www.xlhg.com). $3,3^{\prime}, 5,5^{\prime}$-tetramethylbenzidine (TMB), glucose oxidase $(180 \mathrm{U} / \mathrm{mg})$, and rhodamine B (RhB) were purchased from Aladdin Reagent Co. Ltd. (Shanghai, China; http://www .aladdine.com). Ultrapure water $(18.2 \Omega \mathrm{cm})$ was prepared by a Milli-Q system (Millipore, Bedford, MA, USA; http:// www.merckmillipore.com) and used in all experiments.

2.2. Analytical Methods. The morphology and size distribution of the nanoparticles were studied using a Tecnai-G2 F20 transmission electron microscope (TEM) with an accelerating voltage of $200 \mathrm{kV}$ (FEI; http://www.fei.com). X-ray photoelectron spectroscopy (XPS) was performed using a Thermo Escalab 250 Xi photoelectron spectrometer (Thermo Fisher; http://www.thermoscientific.com). Fourier transform infrared (FTIR) spectra were recorded using a Magna-IR 750 Fourier transform infrared spectrometer (Nicolet; http:// www.thermofisher.com), and absorption spectra were obtained using a SPECORD 200 PLUS UV-vis spectrometer (Analytik Jena; http://www.analytik-jena.com.cn).
2.3. Synthesis of the N, Fe-CDs. The N, Fe-CDs were prepared using a one-step hydrothermal synthesis method [21,27]. Briefly, $0.5 \mathrm{~g}$ of $\beta$-cyclodextrin, $2 \mathrm{~mL}$ of ethylenediamine, and $0.5 \mathrm{~g}$ of $\mathrm{FeCl}_{3} \cdot 6 \mathrm{H}_{2} \mathrm{O}$ were firstly dissolved in $50 \mathrm{~mL}$ of ultrapure water. Then, the solution was transferred to a Teflon-lined, stainless-steel autoclave and heated at $180^{\circ} \mathrm{C}$ for $0.5 \mathrm{~h}$. The mixture was then cooled to room temperature and filtered through a $0.22 \mu \mathrm{m}$ filter under the negative pressure by the water pump. The supernatant was dialyzed against ultrapure water for 24 hours, and then freeze-dried for later use. As control, N-CDs were synthesized in the same way but without $\mathrm{FeCl}_{3} \cdot 6 \mathrm{H}_{2} \mathrm{O}$.

2.4. Mimic Peroxidase Activity of the N, Fe-CDs. The mimic peroxidase activity of $\mathrm{N}, \mathrm{Fe}-\mathrm{CD}$ s was determined using the following procedures. First, $100 \mu \mathrm{L}$ of $\mathrm{N}, \mathrm{Fe}-\mathrm{CDs}$ $(150 \mu \mathrm{g} / \mathrm{mL})$ was added to an acetic acid solution $(0.1 \mathrm{M}$, $\mathrm{pH} 2.5$ ) containing $100 \mu \mathrm{M} \mathrm{H}_{2} \mathrm{O}_{2}$ and $700 \mu \mathrm{M} \mathrm{TMB}$. Color changes were observed after the solution had been incubated in a $35^{\circ} \mathrm{C}$ water bath for $36 \mathrm{~min}$. In order to investigate the catalytic mechanism, the experiment was repeated using different concentrations of TMB and $\mathrm{H}_{2} \mathrm{O}_{2}$. Then, the key 


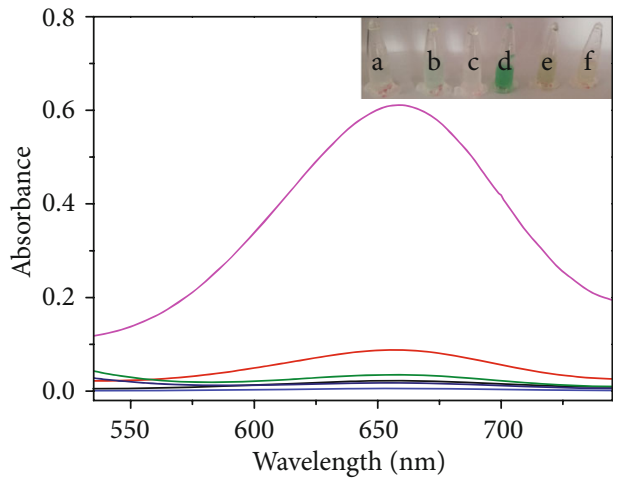

- (a) $\mathrm{TMB}$
(b) $\mathrm{N}-\mathrm{CDs}+\mathrm{TMB}+\mathrm{H}_{2} \mathrm{O}_{2}$
(c) $\mathrm{TMB}+\mathrm{H}_{2} \mathrm{O}_{2}$
(d) $\mathrm{N}, \mathrm{Fe}-\mathrm{CDs}+\mathrm{TMB}+\mathrm{H}_{2} \mathrm{O}_{2}$
- (e) $\mathrm{N}-\mathrm{CDs}+\mathrm{TMB}$
(f) $\mathrm{N}, \mathrm{Fe}-\mathrm{CD}+\mathrm{TMB}$

Figure 3: UV-vis spectra of TMB (a), N-CDs $+\mathrm{TMB}+\mathrm{H}_{2} \mathrm{O}_{2}$ (b), $\mathrm{TMB}+\mathrm{H}_{2} \mathrm{O}_{2}$ (c), N, Fe-CDs $+\mathrm{TMB}+\mathrm{H}_{2} \mathrm{O}_{2}$ (d), $\mathrm{N}-\mathrm{CDs}+\mathrm{TMB}$ (e) and $\mathrm{N}, \mathrm{Fe}-\mathrm{CDs}+\mathrm{TMB}(\mathrm{f})$. Inset: corresponding photographs of different reaction systems.

kinetic parameters were calculated from the double reciprocal Lineweaver-Burk equation:

$$
\frac{1}{V}=\left(\frac{K_{m}}{V_{\max }}\right)\left(\frac{1}{[S]}\right)+\frac{1}{V_{\max }},
$$

where $V$ is the initial velocity, $V$ max is the maximal reaction velocity, and $K m$ is the Michaelis-Menten constant, and $[S]$ is the concentration of the substrate. The initial velocity was obtained by calculating the slopes of absorbance changes at $652 \mathrm{~nm}$ within $100 \mathrm{~s}$.

2.5. RhB Oxidation Experiment. The degradation of $\mathrm{RhB}$ is generally used to demonstrate whether hydroxyl radicals $(\bullet \mathrm{OH})$ are generated during the oxidation of $\mathrm{H}_{2} \mathrm{O}_{2}$. In this work, an aqueous solution of $100 \mu \mathrm{L}$ of $\mathrm{H}_{2} \mathrm{O}_{2}(100 \mu \mathrm{M})$ was added to a solution of $200 \mu \mathrm{L}$ of $\mathrm{RhB}(50 \mu \mathrm{M})$ and $100 \mu \mathrm{L}$ $\mathrm{N}, \mathrm{Fe}-\mathrm{CDs}(150 \mu \mathrm{g} / \mathrm{mL})$, diluted with acetate buffer solution to $1 \mathrm{~mL}$. The reaction was performed for $12 \mathrm{~h}$ in the dark at room temperature. The change in the absorbance of the solution in the range of 200 to $800 \mathrm{~nm}$ was monitored to elucidate the catalytic mechanism.

2.6. Detection of Hydroxyl Radicals Experiment. TA was used as a fluorescence probe for tracking $\bullet \mathrm{OH}$. A standard solution of the TA sodium salt $\left(\mathrm{Na}_{2} \mathrm{TA}\right)$ with a concentration of $25 \mathrm{mM}$ was prepared by dissolving $830.7 \mathrm{mg}$ of $\mathrm{TA}$ in $200 \mathrm{~mL}$ of $\mathrm{NaOH}(62.5 \mathrm{mM})$, and $0.4 \mathrm{~mL}$ of this $\mathrm{Na}_{2} \mathrm{TA}$ solution was added to a mixture of $3.6 \mathrm{~mL}$ acetate buffer solution (100 mM, pH 2.5), $25 \mathrm{mg} / \mathrm{LN}, \mathrm{Fe}-\mathrm{CDs}$, and $0.1 \mathrm{M} \mathrm{H}_{2} \mathrm{O}_{2}$. After incubation at $25^{\circ} \mathrm{C}$ for $12 \mathrm{~h}$ in the dark, the solution was centrifuged and used in the fluorescence measurement. The excitation wavelength used in fluorescence measurement is $315 \mathrm{~nm}$, and the emission wavelength range is from 350 to $600 \mathrm{~nm}$.

2.7. Colorimetric Detection of $\mathrm{H}_{2} \mathrm{O}_{2}$ and Glucose. Colorimetric detection of $\mathrm{H}_{2} \mathrm{O}_{2}$ was performed as follows. A solution containing $200 \mu \mathrm{L}$ of TMB $(700 \mu \mathrm{M}), 100 \mu \mathrm{L}$ of N, Fe-CDs $(150 \mu \mathrm{g} / \mathrm{mL}), 100 \mu \mathrm{L}$ of $\mathrm{H}_{2} \mathrm{O}_{2}$ at different concentrations, and $600 \mu \mathrm{L}$ of acetate buffer $(0.1 \mathrm{M}, \mathrm{pH} 2.5)$ was incubated in a $35^{\circ} \mathrm{C}$ water bath for $36 \mathrm{~min}$. After that, the absorption spectra of the reacted solution were recorded in the range of $500 \mathrm{~nm}$ to $800 \mathrm{~nm}$.

Glucose detection was carried out as follows: first, $20 \mu \mathrm{L}$ of GOx ( $1 \mathrm{mg} / \mathrm{mL}), 20 \mu \mathrm{L}$ of glucose at different concentrations, and $60 \mu \mathrm{L}$ of phosphate-buffered saline (PBS, $0.1 \mathrm{M}$, $\mathrm{pH} 7.0$ ) were mixed and incubated at a $37^{\circ} \mathrm{C}$ water bath for $60 \mathrm{~min}$. Then, $200 \mu \mathrm{L}$ of TMB $(700 \mu \mathrm{M}), 100 \mu \mathrm{L}$ of $\mathrm{N}, \mathrm{Fe}-$ CDs $(150 \mu \mathrm{g} / \mathrm{mL})$, and $600 \mu \mathrm{L}$ of acetate buffer $(0.1 \mathrm{M}$, $\mathrm{pH} 2.5)$ were successively added to the glucose reaction solution and incubated in a water bath at $35^{\circ} \mathrm{C}$ for $36 \mathrm{~min}$. Finally, the UV-vis spectrum of the mixed solution was recorded using a UV-vis spectrometer. Control experiments, in which $0.5 \mathrm{mM}$ glucose was replaced by $5 \mathrm{mM}$ fructose, ascorbic acid, maltose, xylose, uric acid, $\alpha$-lactose, and sucrose, were also performed. Each point was measured three times. The standard errors, defined as the average squared deviation of each number from its mean, were calculated using origin software.

\section{Results and Discussion}

3.1. Characterizations of the $\mathrm{N}, \mathrm{Fe}-\mathrm{CD}$. The TEM image in Figure 1(a) shows that the N, Fe-CDs had good dispersibility, and the size was in the range of $0.9-2.5 \mathrm{~nm}$. FTIR was used to analyze the functional groups in the material. The FTIR spectrum (Figure 1(b)) shows a broad peak at $3328 \mathrm{~cm}^{-1}$, which was ascribed to the stretching vibrations of the $\mathrm{O}-\mathrm{H}$ and $\mathrm{N}$ $\mathrm{H}$ bonds. The intense band at $2920 \mathrm{~cm}^{-1}$ arose from symmetric $\mathrm{C}-\mathrm{H}$ stretching vibrations, and the characteristic band at $1030 \mathrm{~cm}^{-1}$ was assigned to the vibration of the $\mathrm{C}-\mathrm{N}$ bond.

XPS was performed to analyze the composition of the $\mathrm{N}$, $\mathrm{Fe}-\mathrm{CD}$, and the results are shown in Figure 2(a). Four elements $(\mathrm{C}, \mathrm{N}, \mathrm{O}$, and $\mathrm{Fe}$ ) were detected in the XPS spectrum of the $\mathrm{N}, \mathrm{Fe}-\mathrm{CD}$. The oxygen content was found to be as high as $31.78 \%$, which further suggests that the N, Fe-CDs contained abundant functional groups. The main peak at $286.25 \mathrm{eV}$, attributed to $\mathrm{C} 1 \mathrm{~s}$, was deconvoluted into four contributing peaks at 284.5, 285.0, 286.2, and $287.7 \mathrm{eV}$ (Figure 2(b)), which indicates the presence of four carbon environments: $\mathrm{sp}^{2} \mathrm{C}=\mathrm{C}$ or $\mathrm{sp}^{3} \mathrm{C}-\mathrm{C}, \mathrm{C}-\mathrm{N}, \mathrm{sp}^{2} \mathrm{~N}-\mathrm{C}=\mathrm{N}$, and $\mathrm{C}=\mathrm{O}$ [28], respectively. The peak at $399.51 \mathrm{eV}$, attributed to $\mathrm{N} 1 \mathrm{~s}$, was deconvoluted into three contributing peaks at 399.2, 399.8, and 401.5 eV (Figure 2(c)), which indicates the presence of three types of nitrogen environments: C-N, $\mathrm{C}=\mathrm{N}$, and $\mathrm{C}=\mathrm{N}-\mathrm{H}$, respectively [29]. The peak at $532.61 \mathrm{eV}$ was ascribed to $\mathrm{O} 1 \mathrm{~s}$, which can be resolved into 532.0, 532.6, and $533.2 \mathrm{eV}$, corresponding to the $\mathrm{C}-\mathrm{O}, \mathrm{C}=\mathrm{O}$, and $\mathrm{O}-\mathrm{H}$ bonds, respectively [30]. The weak peak at $716.57 \mathrm{eV}$ was ascribed to $\mathrm{Fe} 2 \mathrm{p}$. The content of $\mathrm{Fe}$ was $0.56 \%$, 


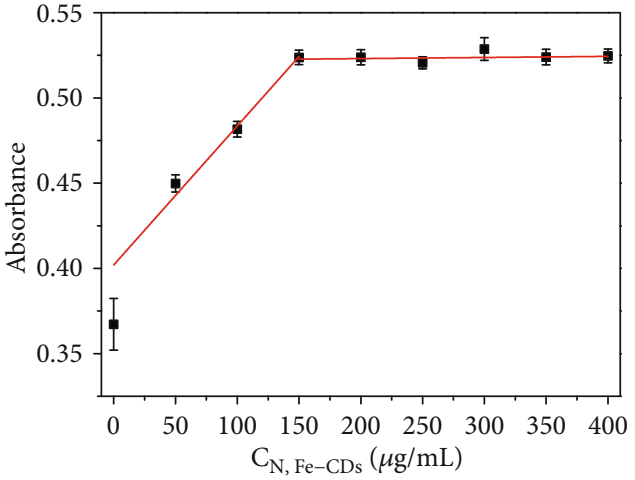

(a)

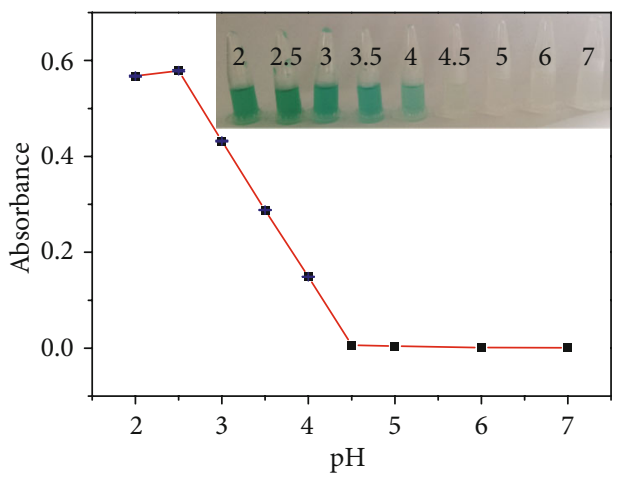

(c)

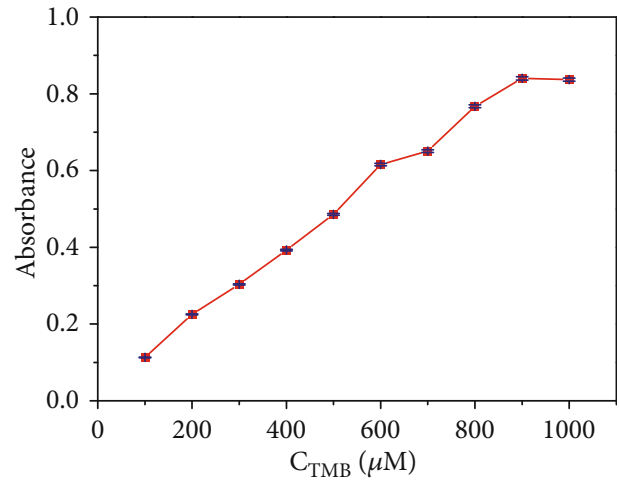

(b)

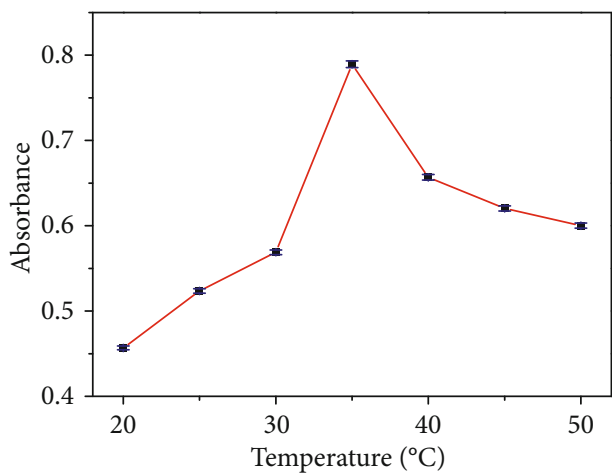

(d)

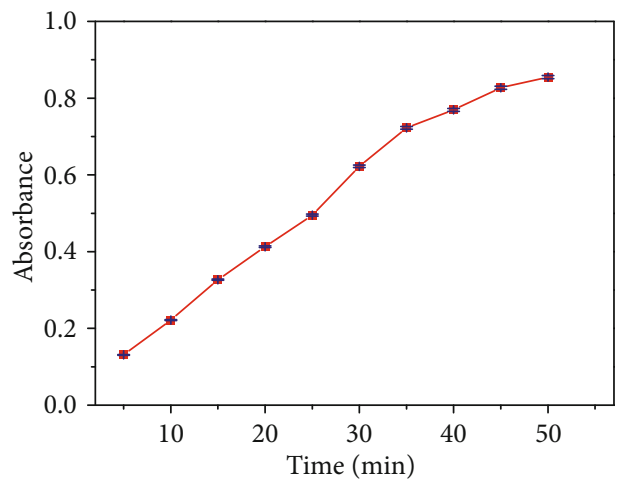

(e)

Figure 4: Influences of the concentration of N, Fe-CDs (a) and TMB (b), pH (c), reaction temperature (d), and reaction duration (e) on the catalytic performance of the $\mathrm{N}, \mathrm{Fe}-\mathrm{CD}$. Inset of $(\mathrm{c})$ : corresponding photographs.

indicating that Fe has been successfully incorporated into the nanoparticles.

\subsection{Evaluation of the Peroxidase-Like Catalytic Activity of the} $\mathrm{N}, \mathrm{Fe}-\mathrm{CDs}$. To investigate the peroxidase-like activity of $\mathrm{N}$, Fe-CDs, colorimetry was carried out using TMB as a substrate in the absence and presence of $\mathrm{H}_{2} \mathrm{O}_{2}$ and $\mathrm{N}, \mathrm{Fe}-\mathrm{CDs}$. As shown in Figure 3, a significant absorption peak appeared at $658 \mathrm{~nm}$ due to oxidation of TMB in the presence of $\mathrm{H}_{2} \mathrm{O}_{2}$ and the N, Fe-CDs (Figure 3(d)). This peak was significantly smaller in the absence of the N, Fe-CDs, which shows that the $\mathrm{N}, \mathrm{Fe}-\mathrm{CD}$ did show great catalytic performance. No significant absorption peaks were observed in the control experiments, including the absence of the $\mathrm{N}$, Fe-CDs
(Figures 3(a) and 3(c)) or $\mathrm{H}_{2} \mathrm{O}_{2}$ (Figure 3(f)) and the replacement of N, Fe-CDs with N-CDs (Figures 3(b) and 3(e)).

The influence of the N, Fe-CDs and TMB concentrations, the $\mathrm{pH}$ value, the reaction temperature, and duration on the catalytic performance were further evaluated, and the results are shown in Figure 4. The absorbance is shown as a function of the N, Fe-CDs concentration in Figure 4(a), interestingly, low concentrations of $\mathrm{N}, \mathrm{Fe}-\mathrm{CD}$ s showed high activity towards TMB oxidation, but the absorbance changed little when the $\mathrm{N}, \mathrm{Fe}-\mathrm{CD}$ s concentration exceeded $150 \mu \mathrm{g} / \mathrm{mL}$. Therefore, a N, Fe-CDs concentration of $150 \mu \mathrm{g} / \mathrm{mL}$ was used in the subsequent experiment. The absorbance increased continuously as the TMB concentration and reaction duration increased. The optimal TMB concentration and reaction 


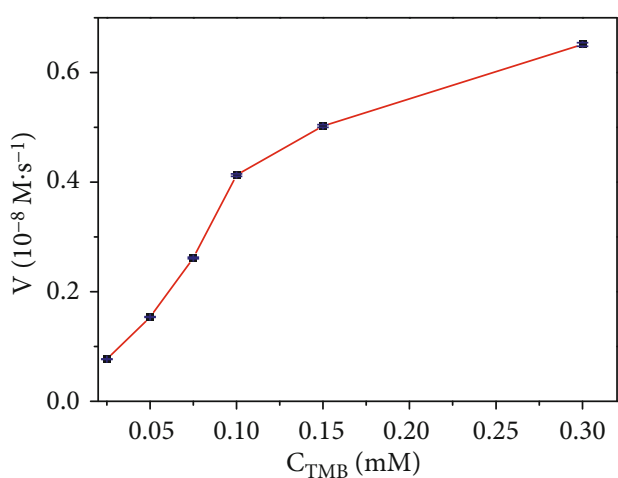

(a)

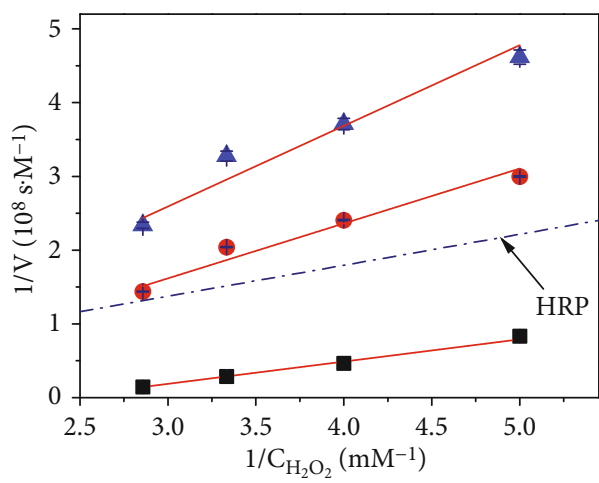

- $\mathrm{H}_{2} \mathrm{O}_{2} 10 \mathrm{mM}$

- $\mathrm{H}_{2} \mathrm{O}_{2} 1 \mathrm{mM}$

$\Delta \mathrm{H}_{2} \mathrm{O}_{2} 0.1 \mathrm{mM}$

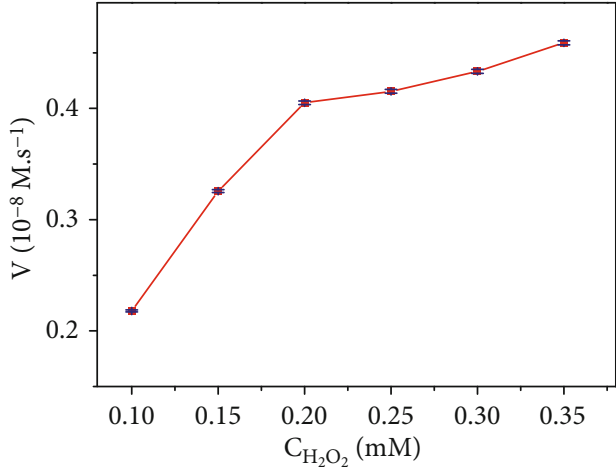

(b)

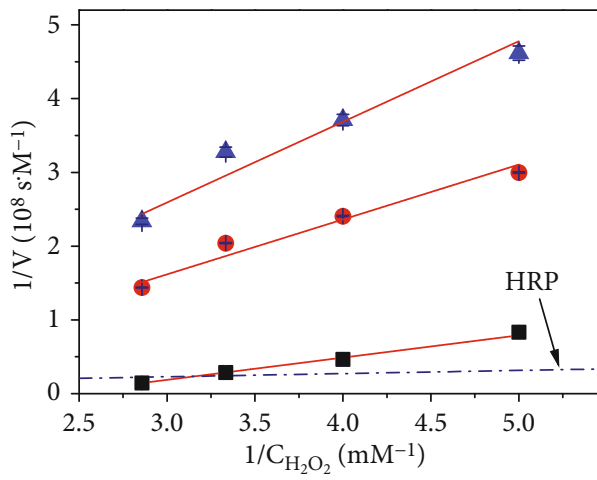

- TMB $1 \mathrm{mM}$

- TMB $0.1 \mathrm{mM}$

$\triangle$ TMB $0.01 \mathrm{mM}$

FIgURE 5: Steady-state kinetic assay of N, Fe-CDs.

TAble 1: Comparison of the apparent Michaelis-Menten constant $(K m)$, maximum reaction rate $(V$ max), and enzyme efficiency $(K m / V$ max $)$ between $\mathrm{N}, \mathrm{Fe}-\mathrm{CDs}$ and HRP.

\begin{tabular}{lccccc}
\hline Catalyst & Substrate & $K m(\mathrm{mM})$ & $V \max \left(10^{-8} \mathrm{M} \cdot \mathrm{s}^{-1}\right)$ & $K m / V \max \left(10^{3} \mathrm{~s}\right)$ & 33.61 \\
$\mathrm{~N}, \mathrm{Fe}-\mathrm{CDs}$ & $\mathrm{TMB}$ & 0.40 & 1.19 & 1.61 & 21.74 \\
& $\mathrm{H}_{2} \mathrm{O}_{2}$ & 0.35 & 10.0 & 4.30 & This work \\
\multirow{2}{*}{$\mathrm{HRP}$} & $\mathrm{TMB}$ & 0.43 & 8.7 & 42.53 & {$[10]$} \\
\hline
\end{tabular}

duration were determined to be $700 \mu \mathrm{M}$ (Figure 4(b)) and $36 \mathrm{~min}$ (Figure 4(e)), respectively. Figure 4(c) shows the change in absorbance caused by varying the $\mathrm{pH}$ from 2.0 to 7.0. The results indicate that catalytic activity of the $\mathrm{N}, \mathrm{Fe}-$ $\mathrm{CDs}$ was highest at a $\mathrm{pH}$ of 2.5 . The catalytic activity of the $\mathrm{N}$, Fe-CDs was also increased when the temperature increased from 25 to $35^{\circ} \mathrm{C}$, but it decreased temperatures higher than $35^{\circ} \mathrm{C}$ (Figure $4(\mathrm{~d})$ ).

In order to better understand the mechanism by which $\mathrm{N}$, Fe-CDs catalyze TMB and $\mathrm{H}_{2} \mathrm{O}_{2}$ oxidation, the apparent steady-state kinetics were measured. As shown in Figures 5(a) and 5(b), a range of TMB and $\mathrm{H}_{2} \mathrm{O}_{2}$ concentrations were used in the catalytic reactions so that the kinetic parameters could be obtained using Lineweaver-Burk plots (Figures 5(C) and 5(D)). Table 1 compares the parameters for this system with those of HRP. A smaller $K m$ value indicates a stronger affinity between the enzyme and the substrate and a higher catalyst efficiency. The $K m$ value for $\mathrm{N}$, Fe-CDs with TMB or $\mathrm{H}_{2} \mathrm{O}_{2}$ as substrate was lower than that of HRP, which suggests that the N, Fe-CDs have a higher affinity for TMB and $\mathrm{H}_{2} \mathrm{O}_{2}$ than HRP does. On the other hand, although the $V \max$ values of the $\mathrm{N}, \mathrm{Fe}-\mathrm{CD}$ sere smaller than those of HRP, the $K m / V$ max value of the $\mathrm{N}$, $\mathrm{Fe}-\mathrm{CDs}$ with $\mathrm{H}_{2} \mathrm{O}_{2}$ as substrate was smaller than those of HRP. The lower the value of $K m / V$ max is, the higher the catalytic efficiency is. Considering their peroxidase mimetic activity, the N, Fe-CDs could be employed as a potential substitute for HRP.

The fitted Lineweaver-Burk lines were nearly parallel at different concentrations of TMB and $\mathrm{H}_{2} \mathrm{O}_{2}$. That means the 


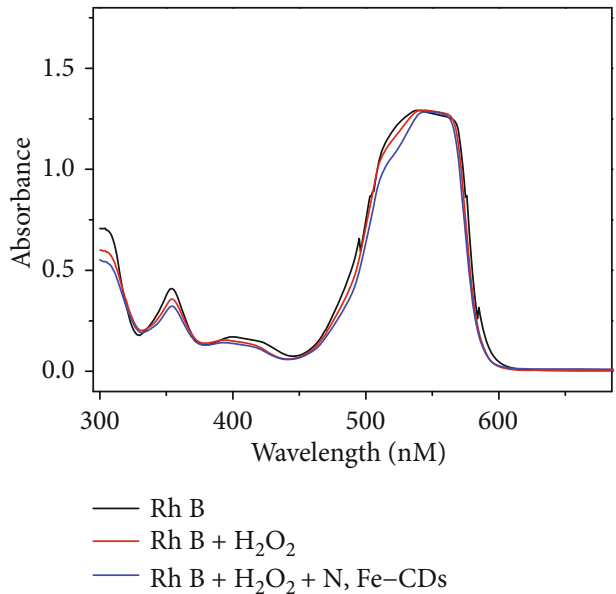

(a)

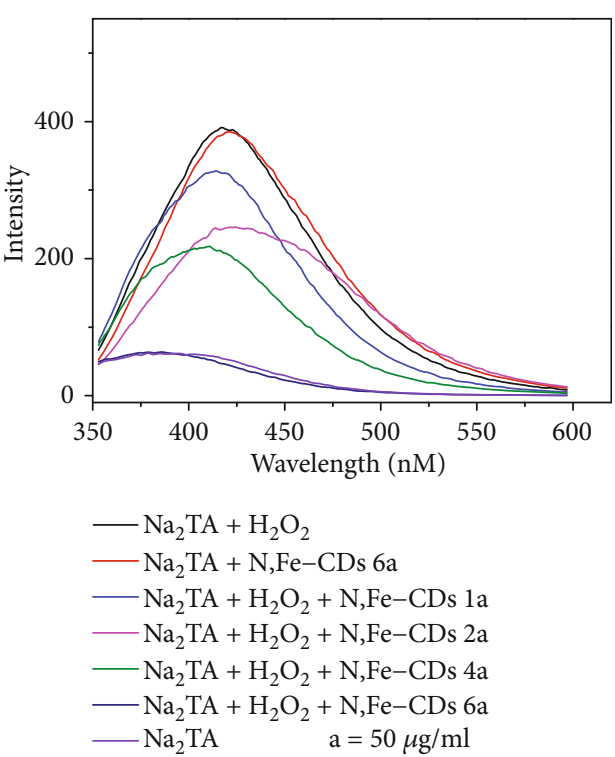

(b)

FIGURE 6: Determining the mechanism of the peroxidase-like activity of N, Fe-CDs. (a) UV-vis absorption spectra of RhB incubated with N, $\mathrm{Fe}-\mathrm{CDs}$. (b) Fluorescence spectra of $\mathrm{Na}_{2} \mathrm{TA}$ incubated with different concentrations of $\mathrm{N}, \mathrm{Fe}-\mathrm{CDs}$.

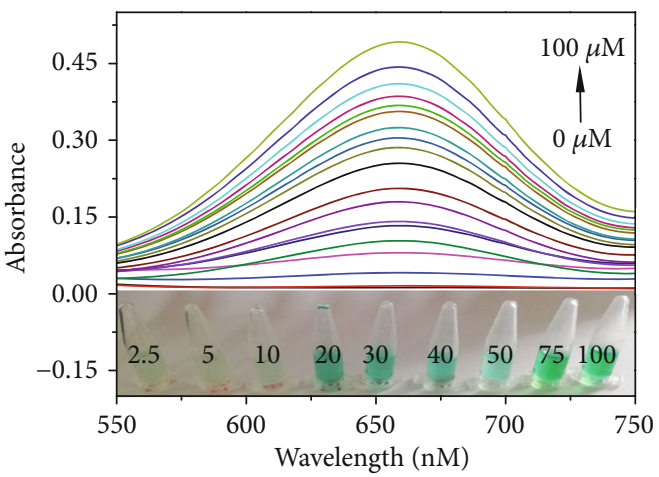

(a)

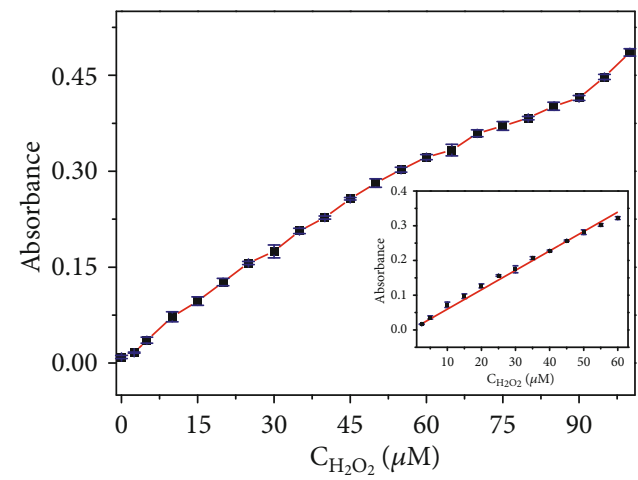

(b)

Figure 7: Typical UV-vis absorption spectra at different $\mathrm{H}_{2} \mathrm{O}_{2}$ concentrations with $\mathrm{N}$, Fe-CDs as a mimic peroxidase. Inset: corresponding photographs. (a) A dose-response curve for $\mathrm{H}_{2} \mathrm{O}_{2}$ detection. Inset: linear calibration plot for $\mathrm{H}_{2} \mathrm{O}_{2}$ (b).

$\mathrm{N}, \mathrm{Fe}-\mathrm{CD}$ s bind to and react with the first substrate, release the product, then recombine with the second substrate, react and release the second product in a manner similar to the ping-pong mechanism of HRP $[31,32]$.

3.3. Mechanism of the Peroxidase-like Activity of N, Fe-CDs. Generally, the catalytic pathway for peroxidase-like activity can be divided into two types, reactive oxygen species generation and an electron transfer process [33-35]. To evaluate the possible active intermediates in the present system, various fluorescent and colorimetric probes were employed. RhB was used to detect $\bullet \mathrm{OH}$ as the presence of $\bullet \mathrm{OH}$ would cause a decrease in the absorbance intensity of RhB. Figure 6(a) shows the change in absorbance of a solution containing $\mathrm{RhB}, \mathrm{H}_{2} \mathrm{O}_{2}$, and $\mathrm{N}, \mathrm{Fe}-\mathrm{CDs}$. After reacting for $12 \mathrm{~h}$, a negligible decrease in the absorbance was observed compared with the control experiments, which indicates the absence of - $\mathrm{OH}$ in the peroxidase-like catalytic process. TA was used as a fluorescence probe for tracking $\bullet \mathrm{OH}$, because it can capture $\bullet \mathrm{OH}$ and generate 2-hydroxyterephthalic acid, thereby emitting a unique fluorescence signal at around $425 \mathrm{~nm}$. After reacting for $12 \mathrm{~h}$, the fluorescence of a solution containing $\mathrm{Na}_{2} \mathrm{TA}, \mathrm{H}_{2} \mathrm{O}_{2}$, and different concentrations of $\mathrm{N}, \mathrm{Fe}-\mathrm{CDs}$ was lower than that of the mixture of $\mathrm{Na}_{2} \mathrm{TA}$ and $\mathrm{H}_{2} \mathrm{O}_{2}$ (Figure 6(b)). These results show that $\bullet \mathrm{OH}$ is not generated as a reaction intermediate during the peroxidase-like catalysis. The reaction route may be described by following reaction equations.

$$
\begin{aligned}
& T M B-e^{-} \longrightarrow o x-T M B \\
& \mathrm{H}_{2} \mathrm{O}_{2}+2 \mathrm{H}^{+}+2 e^{-} \longrightarrow 2 \mathrm{H}_{2} \mathrm{O}
\end{aligned}
$$

3.4. Detection of $\mathrm{H}_{2} \mathrm{O}_{2}$ and Glucose. On the basis of the peroxidase mimetic activity of the N, Fe-CDs, an efficient and fast colorimetric method for the detection of $\mathrm{H}_{2} \mathrm{O}_{2}$ was created. A typical $\mathrm{H}_{2} \mathrm{O}_{2}$ concentration-absorbance profile is shown in Figure $7(\mathrm{a})$. The magnitude of the peak at 


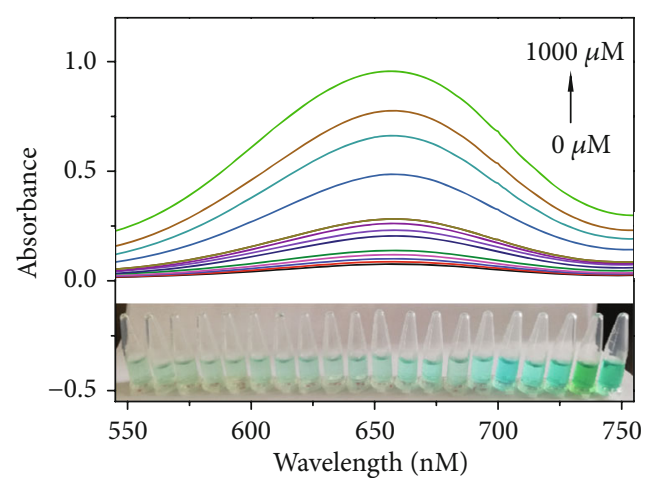

(a)

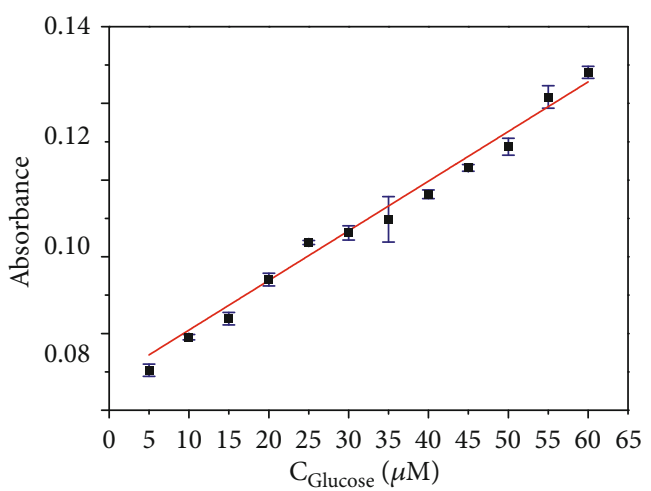

(c)

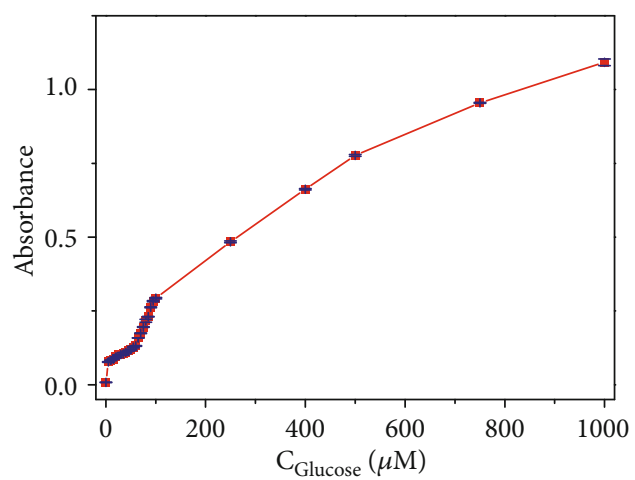

(b)

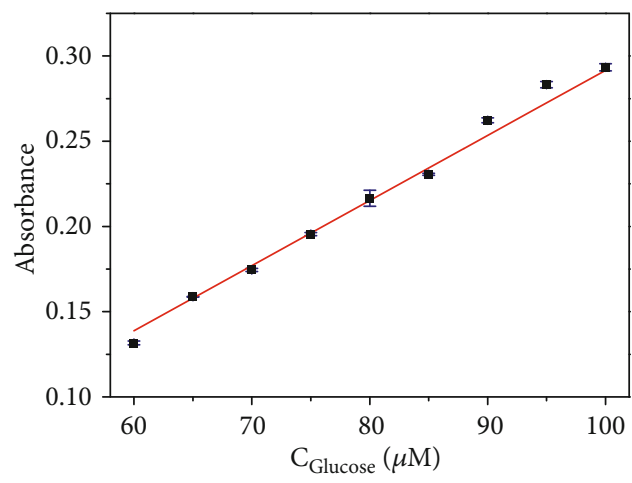

(d)

FIgURE 8: UV-vis absorption spectra of solutions with different concentrations of glucose and $\mathrm{N}, \mathrm{Fe}-\mathrm{CD}$ as a mimic peroxidase. Inset: corresponding photographs (a). A dose-response curve for glucose detection (b). Linear calibration plots for glucose in the range of 0 $60 \mu \mathrm{M}(\mathrm{c})$. Linear calibration plots for glucose in the range of $60-100 \mu \mathrm{M}(\mathrm{d})$.

$658 \mathrm{~nm}$ increased with the increased concentration of $\mathrm{H}_{2} \mathrm{O}_{2}$. A linear relationship between the absorbance and the $\mathrm{H}_{2} \mathrm{O}_{2}$ concentration from 0 to $60 \mu \mathrm{M}$ was obtained $(R 2=0.9932)$, and the limit of detection (LOD) was calculated to be $0.52 \mu \mathrm{M}$ based on three times the standard deviation rule $(\mathrm{LOD}=3 \mathrm{Sd} / \mathrm{k})$. Also, the color of the mixture changed (inset of Figure $7(\mathrm{a})$ ), which indicates that $\mathrm{H}_{2} \mathrm{O}_{2}$ can be detected with the naked eye.

As glucose would be oxidized to $\mathrm{H}_{2} \mathrm{O}_{2}$ and gluconic acid in the presence of glucose oxidase, this method can be used to detect glucose indirectly when combined with the catalytic properties of GOx and N, Fe-CDs. Figure 8(a) shows that the absorbance at the peak of $658 \mathrm{~nm}$ increased as the concentration of glucose increased. There exist two parts of linear range between the absorbance and the concentration of glucose in the range of 0 to $60 \mu \mathrm{M}$ and 60 to $100 \mu \mathrm{M}$ (Figures $8(\mathrm{~b})-8(\mathrm{~d})$ ). The LOD was calculated to be $3.0 \mu \mathrm{M}$. As shown in Table 2, this method was comparable or more sensitive than other reported systems based on different nanoparticles as peroxidase mimics.

To further investigate the specificity of this method, five other sugars (fructose, maltose, xylose, $\alpha$-lactose, and sucrose), ascorbic acid, and uric acid were selected as interfering substances for detection. Figure 9 shows the absorbance at $658 \mathrm{~nm}$ of solutions containing the other sugars, ascorbic acid, and uric acid at concentrations that were ten times higher than that of glucose $(0.5 \mathrm{mM})$. The absorbance
TABle 2: Comparison of glucose detection using different nanoparticles as peroxidase mimics.

\begin{tabular}{lccc}
\hline Peroxidase mimic & $\begin{array}{c}\text { Linear range } \\
(\mu \mathrm{M})\end{array}$ & $\begin{array}{c}\text { Limit of detection } \\
(\mu \mathrm{M})\end{array}$ & Ref. \\
\hline $\mathrm{Fe}_{3} \mathrm{O}_{4} @ \mathrm{CNPs}$ & $1-10$ & 1.12 & {$[8]$} \\
$\mathrm{Por}_{\mathrm{CeO}} \mathrm{NPs}$ & $0-150$ & 19.0 & {$[36]$} \\
$\mathrm{MnO}_{2}$-NWs & $10-2000$ & 2.0 & {$[37]$} \\
Gum kondagogu- & $10-1000$ & 6.0 & {$[38]$} \\
$\mathrm{PdNPs}$ & $50-2000$ & 23.0 & {$[39]$} \\
$2 \mathrm{D} \mathrm{NiFe}-\mathrm{LDHNS}$ & $0.7-300$ & 0.7 & {$[40]$} \\
$\mathrm{C}-\mathrm{dots} / \mathrm{V}_{2} \mathrm{O}_{5}$ & $80-3000$ & 50 & {$[41]$} \\
$\mathrm{HRP}-\mathrm{GOx}$ & $0-60 ; 60-100$ & 3.0 & This \\
$\mathrm{N}, \mathrm{Fe}-\mathrm{CDs}$ & & & work \\
\hline
\end{tabular}

of the other substances differs little from that of the blank (glucose-free) sample, which shows that this method has good glucose selectivity.

\section{Conclusions}

As a conclusion, $\mathrm{N}, \mathrm{Fe}-\mathrm{CD}$ s were synthesized from $\beta$-cyclodextrin, ethylenediamine, and $\mathrm{FeCl}_{3} \cdot 6 \mathrm{H}_{2} \mathrm{O}$ using a one-step hydrothermal method for the first time. The raw materials are easily available, and the preparation process is 


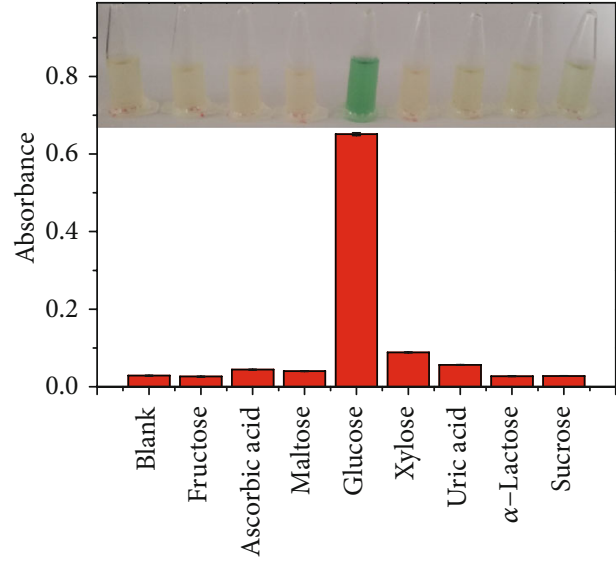

(a)

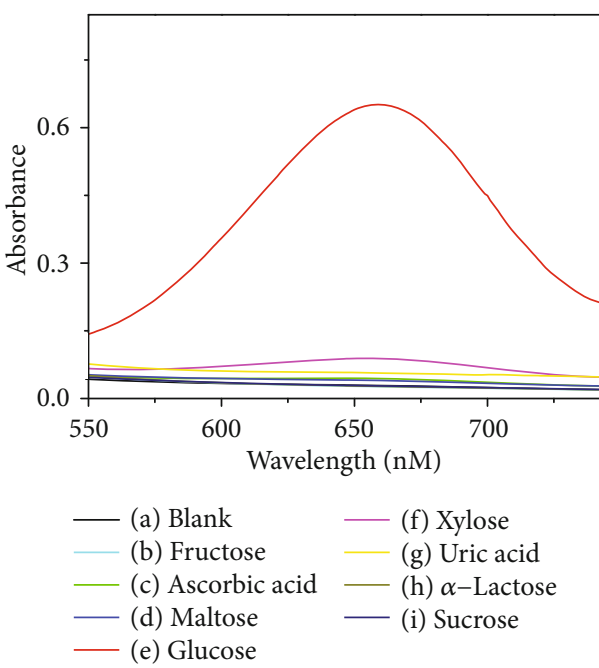

(b)

FIGURE 9: Selectivity of glucose detection in the presence of $5 \mathrm{mM}$ ascorbic acid, $5 \mathrm{mM}$ uric acid, $5 \mathrm{mM}$ other sugars (fructose, maltose, xylose, $\alpha$-lactose, and sucrose), and $0.5 \mathrm{mM}$ glucose (a). Inset: corresponding photographs. The comparison of absorbance for glucose and control compounds (b).

convenient. The obtained N, Fe-CDs exhibited good activity of mimic peroxidase. In the presence of $\mathrm{H}_{2} \mathrm{O}_{2}$, the catalytic oxidation of TMB by $\mathrm{N}, \mathrm{Fe}-\mathrm{CD}$ can produce green watersoluble products. This catalytic oxidation process conforms to the Michaelis-Menten model, and the N, Fe-CDs demonstrated better activity than HRP. On this basis, a highly sensitive and selective colorimetric method was developed for the detection of $\mathrm{H}_{2} \mathrm{O}_{2}$ and glucose. The LODs of $\mathrm{H}_{2} \mathrm{O}_{2}$ and glucose were 0.52 and $3.0 \mu \mathrm{M}$, respectively. This study presents an artificial enzyme that may replace natural peroxidases in biomedical and environmental testing.

\section{Data Availability}

Some or all data, models, or code generated or used during the study are available in a repository or online in accordance with funder data retention policies.

\section{Conflicts of Interest}

The authors have declared no conflict of interest.

\section{Acknowledgments}

This work was supported by Major Science and Technology Projects of Zhangzhou City (No. zz2018ZD20), and the Natural Science Foundation of Fujian Province of China (Nos. 2016Y0065 and 2019S0031).

\section{References}

[1] X. Chen, X. Tian, B. Su, Z. Huang, X. Chen, and M. Oyama, "Au nanoparticles on citrate-functionalized graphene nanosheets with a high peroxidase-like performance," Dalton Transactions, vol. 43, no. 20, pp. 7449-7454, 2014.

[2] J. Cui, S. Ren, B. Sun, and S. Jia, "Optimization protocols and improved strategies for metal-organic frameworks for immo- bilizing enzymes: current development and future challenges," Coordination Chemistry Reviews, vol. 370, pp. 22-41, 2018.

[3] O. Barbosa, C. Ortiz, Á. Berenguer-Murcia, R. Torres, R. C. Rodrigues, and R. Fernandez-Lafuente, "Strategies for the one-step immobilization-purification of enzymes as industrial biocatalysts," Biotechnology Advances, vol. 33, no. 5, pp. 435456, 2015.

[4] E. Shoji and M. S. Freund, "Potentiometric sensors based on the inductive effect on the $\mathrm{p} K_{\mathrm{a}}$ of poly(aniline): a nonenzymatic glucose sensor," Journal of the American Chemical Society, vol. 123, no. 14, pp. 3383-3384, 2001.

[5] X.-L. Zhong, S.-H. Wen, Y. Wang et al., "Colorimetric and electrochemical arsenate assays by exploiting the peroxidaselike activity of $\mathrm{FeOOH}$ nanorods," Microchimica Acta, vol. 186, no. 11, 2019.

[6] Y. Z. Li, T. T. Li, W. Chen, and Y. Y. Song, " $\mathrm{Co}_{4} \mathrm{~N}$ nanowires: noble-metal-free peroxidase mimetic with excellent salt- and temperature-resistant abilities," ACS Applied Materials \& Interfaces, vol. 9, no. 35, pp. 29881-29888, 2017.

[7] T. M. Chen, X. J. Wu, J. X. Wang, and G. W. Yang, "WSe $e_{2}$ few layers with enzyme mimic activity for high-sensitive and highselective visual detection of glucose," Nanoscale, vol. 9, no. 32, pp. 11806-11813, 2017.

[8] N. Lu, M. Zhang, L. Ding et al., "Yolk-shell nanostructured $\mathrm{Fe}_{3} \mathrm{O}_{4} @ \mathrm{C}$ magnetic nanoparticles with enhanced peroxidaselike activity for label-free colorimetric detection of $\mathrm{H}_{2} \mathrm{O}_{2}$ and glucose," Nanoscale, vol. 9, no. 13, pp. 4508-4515, 2017.

[9] L. Han, P. Liu, H. Zhang, F. Li, and A. Liu, "Phage capsid protein-directed $\mathrm{MnO}_{2}$ nanosheets with peroxidase-like activity for spectrometric biosensing and evaluation of antioxidant behaviour," Chemical Communications, vol. 53, no. 37, pp. 5216-5219, 2017.

[10] A. H. Valekar, B. S. Batule, M. I. Kim et al., "Novel aminefunctionalized iron trimesates with enhanced peroxidase-like activity and their applications for the fluorescent assay of choline and acetylcholine," Biosensors and Bioelectronics, vol. 100, pp. 161-168, 2018. 
[11] X. Jiang, C. Sun, Y. Guo, G. Nie, and L. Xu, "Peroxidase-like activity of apoferritin paired gold clusters for glucose detection," Biosensors and Bioelectronics, vol. 64, pp. 165-170, 2015.

[12] J. Wu, X. Wang, Q. Wang et al., "Nanomaterials with enzymelike characteristics (nanozymes): next-generation artificial enzymes (II)," Chemical Society Reviews, vol. 48, no. 4, pp. 1004-1076, 2019.

[13] H.-H. Xu, H.-H. Deng, X.-Q. Lin et al., "Colorimetric glutathione assay based on the peroxidase-like activity of a nanocomposite consisting of platinum nanoparticles and graphene oxide," Microchimica Acta, vol. 184, no. 10, pp. 3945-3951, 2017.

[14] Y. Song, X. Wang, C. Zhao, K. Qu, J. Ren, and X. Qu, "Labelfree colorimetric detection of single nucleotide polymorphism by using single-walled carbon nanotube intrinsic peroxidaselike activity," Chemistry - A European Journal, vol. 16, no. 12, pp. 3617-3621, 2010.

[15] W. Shi, Q. Wang, Y. Long et al., "Carbon nanodots as peroxidase mimetics and their applications to glucose detection," Chemical Communications, vol. 47, no. 23, pp. 6695-6697, 2011.

[16] T. Lin, L. Zhong, J. Wang et al., "Graphite-like carbon nitrides as peroxidase mimetics and their applications to glucose detection," Biosensors and Bioelectronics, vol. 59, pp. 89-93, 2014.

[17] X. Wu, Y. Zhang, T. Han, H. Wu, S. Guo, and J. Zhang, "Composite of graphene quantum dots and $\mathrm{Fe}_{3} \mathrm{O}^{4}$ nanoparticles: peroxidase activity and application in phenolic compound removal," RSC Advances, vol. 4, no. 7, pp. 3299-3305, 2014.

[18] D. Zhou, C. Wang, J. Luo, and M. Yang, " $\mathrm{C}_{3} \mathrm{~N}_{4}$ nanosheetsupported Prussian Blue nanoparticles as a peroxidase mimic: colorimetric enzymatic determination of lactate," Microchimica Acta, vol. 186, no. 11, 2019.

[19] W. Wang, X. Jiang, and K. Chen, "Iron phosphate microflowers as peroxidase mimic and superoxide dismutase mimic for biocatalysis and biosensing," Chemical Communications, vol. 48, no. 58, pp. 7289-7291, 2012.

[20] M. Shamsipur, K. Molaei, F. Molaabasi et al., "Facile preparation and characterization of new green emitting carbon dots for sensitive and selective off/on detection of $\mathrm{Fe}^{3+}$ ion and ascorbic acid in water and urine samples and intracellular imaging in living cells," Talanta, vol. 183, pp. 122-130, 2018.

[21] N. Amin, A. Afkhami, L. Hosseinzadeh, and T. Madrakian, "Green and cost-effective synthesis of carbon dots from date kernel and their application as a novel switchable fluorescence probe for sensitive assay of Zoledronic acid drug in human serum and cellular imaging," Analytica Chimica Acta, vol. 1030, pp. 183-193, 2018.

[22] H. Jia, D. Yang, X. Han, J. Cai, H. Liu, and W. He, "Peroxidaselike activity of the $\mathrm{Co}_{3} \mathrm{O}_{4}$ nanoparticles used for biodetection and evaluation of antioxidant behavior," Nanoscale, vol. 8, no. 11, pp. 5938-5945, 2016.

[23] Y. Lin, J. Ren, and X. Qu, "Catalytically active nanomaterials: a promising candidate for artificial enzymes," Accounts of Chemical Research, vol. 47, no. 4, pp. 1097-1105, 2014.

[24] V. Arul, T. N. J. I. Edison, Y. R. Lee, and M. G. Sethuraman, "Biological and catalytic applications of green synthesized fluorescent N-doped carbon dots using Hylocereus undatus," Journal of Photochemistry and Photobiology B: Biology, vol. 168, pp. 142-148, 2017.

[25] D. Jampaiah, T. Srinivasa Reddy, A. E. Kandjani et al., "Fedoped $\mathrm{CeO}_{2}$ nanorods for enhanced peroxidase-like activity and their application towards glucose detection," Journal of Materials Chemistry B, vol. 4, no. 22, pp. 3874-3885, 2016.

[26] N. Vasileva, T. Godjevargova, D. Ivanova, and K. Gabrovska, "Application of immobilized horseradish peroxidase onto modified acrylonitrile copolymer membrane in removing of phenol from water," International Journal of Biological Macromolecules, vol. 44, no. 2, pp. 190-194, 2009.

[27] B. Wang, F. Liu, Y. Wu, Y. Chen, B. Weng, and C. M. Li, "Synthesis of catalytically active multielement-doped carbon dots and application for colorimetric detection of glucose," Sensors and Actuators B: Chemical, vol. 255, pp. 2601-2607, 2018.

[28] J. Xian, Y. Weng, H. Guo, Y. Li, B. Yao, and W. Weng, “Onepot fabrication of Fe-doped carbon nitride nanoparticles as peroxidase mimetics for $\mathrm{H}_{2} \mathrm{O}_{2}$ and glucose detection," Spectrochimica Acta Part A: Molecular and Biomolecular Spectroscopy, vol. 215, pp. 218-224, 2019.

[29] W. Yang, T. T. Huang, M. Zhao et al., "High peroxidase-like activity of iron and nitrogen co-doped carbon dots and its application in immunosorbent assay," Talanta, vol. 164, pp. 1-6, 2017.

[30] Y. C. Lu, J. Chen, A. J. Wang et al., "Facile synthesis of oxygen and sulfur co-doped graphitic carbon nitride fluorescent quantum dots and their application for mercury ${ }_{\text {II }}$ ) detection and bioimaging," Journal of Materials Chemistry C, vol. 3, no. 1, pp. 73-78, 2015.

[31] L. Huang, Z. Li, and L. Guo, "Colorimetric assay of acetylcholinesterase inhibitor tacrine based on $\mathrm{MoO}_{2}$ nanoparticles as peroxidase mimetics," Spectrochimica Acta Part A: Molecular and Biomolecular Spectroscopy, vol. 224, p. 117412, 2020.

[32] W. Dong and Y. Huang, " $\mathrm{CeO}_{2} / \mathrm{C}$ nanowire derived from a cerium (III) based organic framework as a peroxidase mimic for colorimetric sensing of hydrogen peroxide and for enzymatic sensing of glucose," Microchimica Acta, vol. 187, no. 1, 2020.

[33] M. Dervisevic, E. Dervisevic, and M. Şenel, "Recent progress in nanomaterial-based electrochemical and optical sensors for hypoxanthine and xanthine. A review," Microchimica Acta, vol. 186, no. 12, 2019.

[34] E. Eskandari, M. Kosari, M. H. Davood Abadi Farahani et al., "A review on polyaniline-based materials applications in heavy metals removal and catalytic processes," Separation and Purification Technology, vol. 231, p. 115901, 2020.

[35] H. Yang, Z. Wang, Q. Zhou, C. Xu, and J. Hou, "Nanoporous platinum-copper flowers for non-enzymatic sensitive detection of hydrogen peroxide and glucose at near-neutral $\mathrm{pH}$ values," Microchimica Acta, vol. 186, no. 9, 2019.

[36] Q. Liu, Y. Yang, X. Lv et al., “One-step synthesis of uniform nanoparticles of porphyrin functionalized ceria with promising peroxidase mimetics for $\mathrm{H}_{2} \mathrm{O}_{2}$ and glucose colorimetric detection," Sensors and Actuators B: Chemical, vol. 240, pp. 726-734, 2017.

[37] L. Han, J. Shi, and A. Liu, "Novel biotemplated $\mathrm{MnO}_{2} 1 \mathrm{D}$ nanozyme with controllable peroxidase-like activity and unique catalytic mechanism and its application for glucose sensing," Sensors and Actuators B: Chemical, vol. 252, pp. 919-926, 2017.

[38] L. Rastogi, D. Karunasagar, R. B. Sashidhar, and A. Giri, "Peroxidase-like activity of gum kondagogu reduced/stabilized palladium nanoparticles and its analytical application for colorimetric detection of glucose in biological samples," Sensors and Actuators B: Chemical, vol. 240, pp. 1182-1188, 2017. 
[39] T. Zhan, J. Kang, X. Li, L. Pan, G. Li, and W. Hou, "NiFe layered double hydroxide nanosheets as an efficiently mimic enzyme for colorimetric determination of glucose and $\mathrm{H}_{2} \mathrm{O}_{2}$," Sensors and Actuators B: Chemical, vol. 255, pp. 2635-2642, 2018.

[40] F. Honarasa, F. H. Kamshoori, S. Fathi, and Z. Motamedifar, "Carbon dots on $\mathrm{V}_{2} \mathrm{O}_{5}$ nanowires are a viable peroxidase mimic for colorimetric determination of hydrogen peroxide and glucose," Microchimica Acta, vol. 186, no. 4, 2019.

[41] F. Wang, W. Gong, L. Wang, and Z. Chen, "Enhanced amperometric response of a glucose oxidase and horseradish peroxidase based bienzyme glucose biosensor modified with a film of polymerized toluidine blue containing reduced graphene oxide," Microchimica Acta, vol. 182, no. 11-12, pp. 19491956, 2015. 